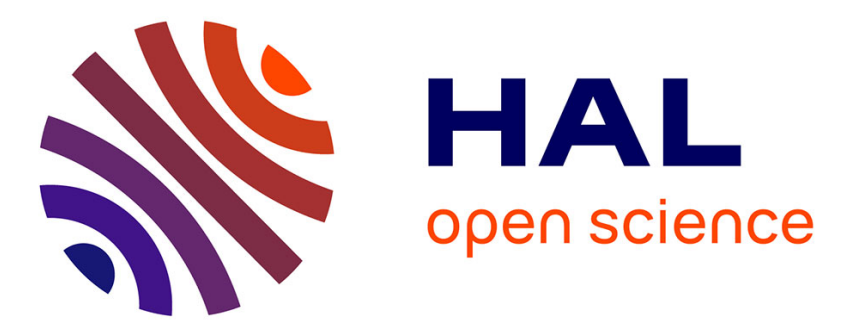

\title{
New ruminants (Mammalia) from the Pliocene of Kanapoi, Kenya, and a revision of previous collections, with a note on the Suidae
}

Denis Geraads, René Bobe, Fredrick Kyalo Manthi

\section{- To cite this version:}

Denis Geraads, René Bobe, Fredrick Kyalo Manthi. New ruminants (Mammalia) from the Pliocene of Kanapoi, Kenya, and a revision of previous collections, with a note on the Suidae. Journal of African Earth Sciences, 2013, 85, pp.53-61. 10.1016/j.jafrearsci.2013.04.006 . hal-01455164

\section{HAL Id: hal-01455164 \\ https://hal.science/hal-01455164}

Submitted on 18 Jan 2018

HAL is a multi-disciplinary open access archive for the deposit and dissemination of scientific research documents, whether they are published or not. The documents may come from teaching and research institutions in France or abroad, or from public or private research centers.
L'archive ouverte pluridisciplinaire HAL, est destinée au dépôt et à la diffusion de documents scientifiques de niveau recherche, publiés ou non, émanant des établissements d'enseignement et de recherche français ou étrangers, des laboratoires publics ou privés. 
1 New ruminants (Mammalia) from the Pliocene of Kanapoi, Kenya, and a

2 revision of previous collections, with a note on the Suidae

3

4 Denis Geraads $^{\text {a, b, * }}$, René Bobe ${ }^{\text {c, d, }}$ Fredrick KyaloManthi ${ }^{\mathrm{c}}$

5

6 a Sorbonne Universités - CR2P-MNHN, CNRS, UPMC-Paris 6 - CP 38, Muséum National

7 d'Histoire Naturelle, 8 rue Buffon, F-75231 Paris Cedex 05, France;

$8{ }^{\mathrm{b}}$ Max Planck Institute for Evolutionary Anthropology, Department of Human Evolution,

9 Deutscher Platz 6 - D-04103 Leipzig-Germany

$10{ }^{\mathrm{c}}$ Departamento de Antropología, Universidad de Chile, Santiago, Chile

11 d Institute of Cognitive \& Evolutionary Anthropology, University of Oxford, Oxford, UK 12

13 * Corresponding author.

14 E-mail address: denis.geraads@mnhn.fr (D. Geraads)

15

16 Keywords: Africa, Pliocene, Kanapoi, Bovidae, Giraffidae

17 


\section{Abstract}

We update here our recent revision of the Kanapoi ruminants and describe recently

21 collected material. We now regard the occurrence of reduncins as doubtful, we revise the

22 identification of a large raphicerin as being more probably Gazella, and we add

23 Gazella cf. janenschi and the Cephalophini to the faunal list. New material of Tragelaphus

24 kyaloi suggests that this species held its head unlike other tragelaphins, and was not an

25 exclusive dedicated browser, but Kanapoi pre-dates the Pliocene change of Sivatherium,

26 Aepyceros, Alcelaphini, and even Tragelaphini towards more grazing diets. Kanapoi shares several ruminant taxa with sites in Ethiopia and Tanzania, attesting to latitudinal exchanges. 
The fossils collected at Kanapoi by the Harvard expeditions led by B. Patterson and by the National Museums of Kenya (KNM) expeditions led by M. Leakey were briefly described by Harris et al. (2003), who also figured the most important specimens. Further collecting at Kanapoi since 2003 significantly increased the collections, and an update on the Ruminantia, together with some more figures, were provided by Geraads et al. (2013a). Since then, more material has been found, allowing us to refine the taxonomy; in addition, we add complements regarding the affinities of the various species, as well as their ecological preferences and biogeographic relationships. Collecting during recent years left out only very fragmentary material, but was certainly less exhaustive in earlier years, e.g., isolated teeth are less common; the present day collection includes about 530 ruminant specimens. The material has been extensively compared with that from other late Miocene to early Pleistocene sites from Kenya in the KNM and National Museum of Ethiopia (NME).

\section{Systematic paleontology}

Family Giraffidae Gray, 1821

Description and comparisons There are only about 40 specimens in this family, but two species of Giraffa can be identified, in addition to Sivatherium.

Genus Giraffa Brisson, 1762

Giraffa jumae Leakey, 1965

KNM-KP 58739 (Fig. 1H) is a short horn whose base is very incomplete but shows that it was inserted above a cranial sinus. It is distinctly more conical than in the modern giraffe Giraffa camelopardalis, but some ossicones of G. jumae from Hadar, such as AL 2911 (Geraads, 2013b), display the same conical shape. It also resembles the horn from Langebaanweg that Harris (1976b) chose as the paratype of his Sivatherium hendeyi, but is much too conical to belong to this genus (Q.B. Hendey pers. comm. to D.G., 1984); it could belong to G. jumae as well. Tooth measurements of the mandible KNM-KP 30450 described by Geraads et al. (2013a) are slightly above the observed maxima for the modern giraffe G. camelopardalis (length of $\mathrm{m} 3=47.7$ vs. $37.5-46, N=36$ ). Several other teeth and limbbones are of a similar large size, but most of them are within the range of the modern form; surprisingly, no astragalus is large enough to belong here. A species distinction from 
KP 30450 is more informative in having a complete lingual wall along the whole crown, rare in the modern form whose $\mathrm{p} 3$ is almost always more primitive, but common in G. jumae both at Hadar (Geraads et al., 2013b) and Langebaanweg (Harris, 1976b). This confirms that this species is probably not ancestral to the modern form; its possible occurrence in Turkey (Geraads, 1998) raises the possibility of an ancient divergence from the late Miocene Eastern Mediterranean Bohlinia. Besides Hadar and the type-locality Olduvai, the species has been reported from several African sites, but this name has uncritically been given to fossil Giraffa of large size, and the history of the genus at species level remains poorly understood. If there are really four species of modern giraffes whose East African members diverged about $2 \mathrm{Ma}$ (Fennessy et al., 2016), one would probably expect to find more camelopardalis-like fossils in the Pleistocene record, and it is likely that this date, based upon exceedingly old dates for the divergence of the Cetartiodactyla main groups, is over estimated.

\section{Giraffa pygmaea Harris, 1976a}

Geraads et al. (2013a) revised the identification of the smaller giraffe of Kanapoi, which was called Giraffa stillei by Harris et al. (2003). KNM-KP 59918 (Fig. 1I) is an incomplete, weathered ossicone of small size. Its apical end forms a terminal knob, as in males of the modern form, showing that it belongs to a small-size species rather than to a female. It does not significantly differ from ER-656, paratype of Giraffa pygmaea (Harris, 1976a:Pl. 9-10).

Several newly discovered astragali confirm the presence of G. pygmaea. No consistent feature seems to distinguish giraffid astragali from those of bovids, but some of these astragali are larger than the numerous astragali of the bovid Ugandax from the Hadar Formation. In addition, in at least some of them, the lateral lip of the proximal trochlea is thick and laterally shifted, as in modern G. camelopardalis, but unlike in bovins. Their measurements (Fig. 2) are slightly lower than those of other East African Giraffa that could belong to either G. pygmaea or small Giraffa stillei: ST-23825 from South Turkwel, ER-2932 from Koobi Fora, and LT-28646 and LT-25451 from Lothagam. Several astragali from Omo are as small as the Kanapoi ones, but might be bovin.

This very small Giraffa is less rare at Kanapoi than in younger sites; Geraads et al. (2013b) surmised that this might be because G. pygmaea evolved into G. stillei, but late Miocene potential ancestors of Giraffa are large, and it is perhaps instead the diminutive size of G. pygmaea that is derived. 
From an ethological point of view, the sharp distinction between the two Giraffa species confirms the observation by Geraads et al. (2013b) that this distinction dwindles in younger sites, contrary to the expectation that character displacement would lead to the opposite, so as to increase niche partitioning and visual recognition. The reasons for this increasing similarity remain unknown.

104

Genus Sivatherium Falconer and Cautley, 1836

Sivatherium cf. hendeyi Harris, 1976b

107

Harris et al. (2003) identified the species on the basis of a partial horn KNM-KP 30449, but the quickly decreasing diameters show that it was far too short for Sivatherium, and it is in fact certainly a bovid horn-core (see below). The only new specimen is KNM-KP 59920, a short, massive first phalanx; it is stouter than in Giraffa and the proximal articulation

112 is broader relative to its antero-posterior diameter, which matches the broad distal metapodials 113 of Sivatherium. Still, the only unequivocal specimens of Sivatherium are the incomplete upper molar KNM-KP 32551 and the tooth fragments KNM-KP 30227; this taxon is thus extremely rare at Kanapoi.

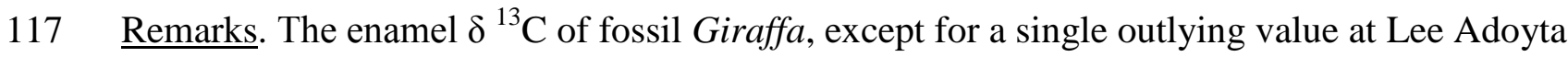

118 (Rowan et al., 2016), shows that this genus consistently remained a browser during the whole 119 Pliocene, and Kanapoi is no exception. By contrast, the diet of Sivatherium in Africa, long 120 debated, rather abruptly changed during the Pliocene, from browser to almost pure grazer, 121 even though this change looks diachronous in the Turkana and Afar basins (Rowan et al., 2016). Sample size is low at Kanapoi, but the $\delta{ }^{13} \mathrm{C}$ values (Supplementary Online Material

123 [SOM] Fig. 1) indicate a browser, or at most a mixed-feeder, certainly far less distinct from

124 Giraffa in its diet than in later sites.

Family Bovidae Gray, 1821

127 Description and comparisons

128 Subfamily Bovinae Gray, 1821

129 Tribe Tragelaphini Blyth, 1863

130 Genus Tragelaphus Blainville, 1816

131 Tragelaphus cf. kyaloi Harris, 1991 
Tragelaphus is by far the most common bovid at Kanapoi, but many specimens are incomplete. The most significant recently collected one is KNM-KP 58836 (Fig. 1A), a braincase with the bases of both horn-cores, unfortunately in bad condition. Together with the previously collected occipital KNM-KP 68 (Fig. 1C), it shows that the Kanapoi Tragelaphus has a distinctive cranial morphology, unlike that of other tragelaphins. The horn-cores are inserted very upright on the skull, the angle between their posterior border and the top of the braincase being about $90^{\circ}$, and even more in KNM-KP 58836. The braincase is short and broad posteriorly; the broad occipital is not vertical as in other Tragelaphus, but forms with the top of the parietal an angle of about $120^{\circ}$ in KNM-KP 58836 (probably less than this in KNM-KP 68, but still certainly more than 90); KNM-KP 30158 shows that the dorsal frontal profile is more arched between the horn-cores than in other tragelaphins; the paroccipital processes are not directed ventrally, but postero-ventrally (as in alcelaphins). The anterior tuberosities of the basioccipital are long and narrow, with a long, narrow groove in between. All these cranial characters are probably correlated and point to a head posture different from that of other tragelaphins, with a less horizontal forehead (Fig. 3).

The only relatively complete horn-cores are those of KNM-KP 30156 (Fig. 1B), but other specimens conform with their morphology. Those whose basal dimensions can be measured are KNM-KP $58792(\mathrm{APD}=44.3 \times \mathrm{TD}=48.2), \mathrm{KNM}-\mathrm{KP} 59682(35 \times 42.5)$, KNM-KP 58725 (33 × 42), KNM-KP 59801 (39 × 47.5), KNM-KP 59802 (31.5 ×36) KNMKP $59807(47.5 \times 60.5)$, and KNM-KP $59831(47.2 \times 58.5)$. The range of variation (Fig. 4) is thus greater than illustrated by Geraads et al. (2013a), but the presence of two species can be rejected because dental size is homogeneous (Geraads et al., 2013). This great variation is comparable to that found in modern tragelaphins that have horns in both sexes (Tragelaphus eurycerus and Tragelaphus oryx); the fossil Tragelaphus nakuae displays a similar large size range (Reed and Bibi, 2011:Fig. 6), and these authors assumed that it also had horned females. It is likely that this was also true of Tragelaphus kyaloi, in agreement with the absence of a hornless skull at Kanapoi. The horn cores have a fairly regular curve,

160 diverging by about $80^{\circ}$ to $90^{\circ}$ at the base, and this divergence somewhat increases upwards 161 and then regularly decreases to the tips, which were relatively close to each other; by contrast, because of the strong basal divergence, the most lateral parts are located far apart. Among modern species, the closest resemblance in course is with the mountain nyala of the Ethiopian highlands, Tragelaphus buxtoni. At the base, the keels are variable but generally poorly indicated; the antero-lateral one is no more than a change in outline curvature and almost vanishes upwards. The lateral one is also usually weak. Because of these weak keels, and 
because the antero-medial part is often expanded, the section is more quadrangular than triangular (Fig. 1D).

\section{We follow Harris et al. (2003) in relating the Kanapoi Tragelaphus to}

Tragelaphus kyaloi Harris, 1991, a species defined at Kosia and about the same age as the Kanapoi specimens ( 4 Ma). The species is very poorly represented outside Kanapoi, but the holotype frontlet closely resembles the Kanapoi form in the course (Harris, 1991:Fig.5.7) and cross-section (Haile-Selassie et al, 2009:Fig. 9.10) of the horn-cores. The only visible differences are that, in the type specimen, the anterior tuberosities of the basioccipital are stronger and the parieto-occipital angle looks smaller; given that these differences concern some of the most remarkable characteristics of the Kanapoi form, we now refrain from formally identifying the Kanapoi species with T. kyaloi.

The Kanapoi Tragelaphus resembles the slightly younger Tragelaphus saraitu from Woranso-Mille in the Awash Valley (Geraads et al., 2009b) in its horn-cores that are uprightly inserted and have similar anteroposterior compression, but it differs in having more regularly curved horn-cores with re-approaching tips, a less triangular cross-section with a fainter anterior keel (especially at the base), its slightly longer braincase, lower and broader occipital that makes a greater angle with the top of the braincase in lateral view, and paroccipital processes directed posteroventrally. T. saraitu, which might already be present at Mursi (Drapeau et al., 2014), is probably an early member of the Tragelaphus rastafariT. nakuae lineage (Geraads et al., 2009b; Reed and Bibi, 2010; Bibi, 2011), suggesting that the divergence from $T$. kyaloi must be earlier. This was problematic because earlier Tragelaphus species are also rather different from T. kyaloi (see Geraads et al., 2013a), except perhaps the scarce material from Lothagam; the new material resolves this issue by showing that the characters of T. kyaloi are clearly derived. Indeed, the quadrangular cross section of the horn-cores and construction of the braincase are so distinctive that in a phenetic classification, a generic distinction would be warranted.

The cranial flexion of the Kanapoi $T$. cf. kyaloi, which implies a muzzle somewhat more inclined ventrally than in browsing tragelaphins, suggests that grasses made up a greater fraction of their diet. Indeed, isotope analyses show that during the whole Pliocene, the tragelaphin diet ranged from browsers to mixed-feeders and even grazers, few of them being strict browsers like modern ones (Cerling et al., 2015); the few available data from Kanapoi also suggest mixed feeding (SOM Fig. 2).

\section{Tribe Bovini Gray, 1821}


Simatherium sp.

The horn-core KNM-KP 30449 (identified by Harris et al., 2003, as belonging to the giraffid Sivatherium) has a rounded cross-section almost devoid of keels, unlike those of Ugandax from Uganda (Cooke and Coryndon, 1970) and Ethiopia (Gentry, 2006; Geraads et al., 2009b, 2012; Haile-Selassie et al., 2009); we tentatively identify it as Simatherium.

On the mandible KNM-KP 96 (Harris et al., 2003:Fig. 23B-C), the metaconid almost completely closes the lingual valley of p4; it is less expanded in KNM-KP 51008 and KNMKP 56877 (which probably represent both sides of the same individual), but on the average it is stronger than in the more recent Hadar and Woranso-Mille Ugandax coryndonae (Gentry, 2006; Geraads et al., 2009b, 2012)

12) and earlier Kuseralee Member of the Middle Awash (Haile-Selassie et al., 2009:Fig. 9.8), confirming that they belong to different lineages.

214 However, the phylogeny of African Bovini remains poorly known and, as noted by Geraads et 215 al. (2013a), nothing supports the identification of the Kanapoi bovin with the Langebaanweg 'S'. demissum, which Gentry (2011) moved to Ugandax.

Sub-family Antilopinae Gray, 1821

Tribe Reduncini Knottnerus-Meyer, 1907?

Reduncini? gen. et sp. indet.

Geraads et al. (2013a) dismissed most of the dental remains assigned to this tribe by Harris et al. (2003) as not belonging here; they were uncertain about the occurrence of this tribe at Kanapoi, and its presence now looks to us even more unlikely.

The only specimens remaining as possible reduncins are the incomplete horn-core KNM-KP 30631 and the lower molar KNM-KP 463 (see Geraads et al. [2013a] for description and discussion), but we will not assert the occurrence of this tribe on the basis of these incomplete pieces.

Tribe Hippotragini Sundevall in Retzius and Lovén, 1845

231 Genus indet., cf. Tchadotragus Geraads et al., 2008 and added some Hippotragini to their list. A few new specimens further increase it, but the 
Hippotragini remain an uncommon group. The horn core base KNM-KP 56824 is somewhat problematic; its absence of keels and torsion, gentle backward curve, faint transverse ridges, and oval cross-section (basal diameters: $39 \times 33$ ) all fit Hippotragini, but the basal sinus looks subdivided, unlike in Tchadotragus and modern hippotragins (although struts may be present: Erdbrink, 1988:Pl. 6). It may be that at that time pneumatization of hippotragin pedicles was less extensive than at present; Saheloryx Geraads et al., 2008 almost certainly belongs to this tribe, in spite of its solid pedicles.

KNM-KP 56843 (Fig. 1F) and KNM-KP 59763 (Fig. 1G) are two moderately worn upper molars that clearly display their occlusal pattern: they have a central enamel island and a spur in the posterior valley, but the labial pillars are less rounded and the entostyle is weaker than in modern Hippotragus. They are distinctly less hypsodont than molars of the Kanapoi bovin. In these features, they resemble more modern Oryx and the primitive Tchadotragus from Chad (Geraads et al., 2008, 2009a), and characters of the lower teeth match those of Tragelaphus fanonei (Geraads et al., 2009a) from the lower Pliocene of Kossom Bougoudi.

On the whole, the Kanapoi hippotragin is at a more primitive evolutionary grade than modern forms and closer to Tchadotragus, but formal identification would not be strongly supported.

Tribe Alcelaphini Brooke in Wallace, 1876

254 Genus Damalacra Gentry, 1980

255 Damalacra harrisi Geraads, Bobe and Manthi, 2013a

No new material definitely attributable to this species has come to light, so that it remains known only by the type-specimen, the braincase with horn-cores KNM-KP 30157 (Harris et al., 2013:Fig. 27). In its long braincase for an alcelaphin and horn-cores with a simple course and no basal swelling, it is a primitive form. Vrba (1997) was the first to observe that it looks morphologically intermediate between the Langebaanweg Damalacra

262 Gentry, 1980 and Parmularius pandatus Gentry, 1987 from Laetoli, the latter of which is 263 more derived in its less simple horn cores. The Kanapoi form is also intermediate in age and a 264 likely ancestor for $P$. pandatus. 
The occurrence of this taxon at Kanapoi is mostly based upon the frontlet KNM-KP

270 71, identified as Damalacra cf. neanica by Harris et al. (2003), but revised and discussed by

271 Geraads et al. (2013a). KNM-KP 58588 could be another horn-core of the same taxon. It

272 lacks the base, but has an oval cross-section whose diameters quickly decrease upwards,

273 showing that is was short. Geraads et al. (2013a) observed that this species is probably also

274 present at Aramis and Laetoli. We tentatively include it in the genus Damalborea, best known

275 from Hadar; it is certainly different from its two known species (Vrba, 1997; Gentry, 2010;

276 Geraads et al., 2012) but remains too poorly known to be named.

Alcelaphini gen. et sp. indet.

Geraads et al. (2013a) regarded the horn-core pieces KNM-KP 30418 and KNM-KP 30633 as distinct from the two above mentioned species, and noted that the mandible KNMKP 31733 is too large to match the horn-cores in size, so that a total of four alcelaphin species might be present. Other alcelaphin dentitions are of homogeneous size, with m3 lengths ranging from $27.5 \mathrm{~mm}$ to c. $31 \mathrm{~mm}(N=7)$, but we do not know whether they represent one species or two (or more) similar-sized ones.

As early as the lower Pliocene, the Alcelaphini were grazers (SOM Fig. 3), and it even seems that this grazing specialization slightly increased during the course of this epoch. The few available isotopic data confirm that they were fully grazers at Kanapoi.

Tribe "Ovibovini" Gray, 1872?

Genus et sp. indet.

The taxon remains known by a single specimen, the partial mandible KNM-KP 66, 294 called aff. Makapania sp. by Geraads et al. (2013a:Fig. 4). Members of this certainly 295 polyphyletic 'tribe' are quite rare in the African fossil record; its main East African 296 representatives are Budorcas churcheri from Hadar (Gentry, 1996), perhaps Nitidarcus from 297 the Middle Awash (Vrba, 1997), and a few remains from Omo. Identification at genus level of 298 the Kanapoi mandible is impossible, especially as dental remains are almost unknown in East 299 Africa, and we now prefer not to suggest affinities with the South African form. 
The impala is a common bovid at Kanapoi but, like most other bovids, it is mostly represented by incomplete horn-cores and dental remains. As far as can be ascertained, there is some variation in horn-core torsion and development of transverse ridges, some specimens looking rather primitive, while others are closer to the morphology of the modern Aepyceros melampus. The lengths at mid-height of three $\mathrm{m} 3 \mathrm{~s}$ are 22, 23, and $24.5 \mathrm{~mm}$; they are thus slightly larger than at Hadar (Geraads et al., 2012) and more similar in size to Australopithecus afarensis from Woranso-Mille (Geraads et al., 2009b). Surprisingly, they are not smaller than the Aepyceros teeth from Laetoli (Gentry, 1987, 2011), although the horncores from this site are larger. The variability of horn-core morphology, limited morphological differences between Aepyceros species, ambiguous indications provided by size, and the fragmentary nature of the remains prevent definite identification; the one suggested by Geraads et al. (2013a) remains the most likely.

As observed by Cerling et al. (2015), many fossil Aepyceros were more grazers than the modern impala. At Kanapoi, this is true of most of the specimens sampled, although two others have low $\delta{ }^{13} \mathrm{C}$ values (SOM Fig. 4); these are the ones listed by Harris et al. (2003), but their accession numbers were not provided, so that we could not check the identifications. It is likely, although by no means certain, that they were misidentified (confused with Tragelaphus?), and this could also be true of some low values in other sites.

Tribe Raphicerini Grubb, 2001 ?

Raphicerus? sp.

Raphicerus is commonly included in the Neotragini, but this tribe is clearly polyphyletic (e.g., Yang et al., 2013) and it is safer to include it in a less comprehensive clade.

330 Bovids of its size are relatively common at Kanapoi, but are mostly represented by incomplete 331 horn-cores and dental remains. Their identifications are difficult because several small bovids share a rather similar dental morphology and simple, spike-like horn-cores lacking characteristic features. In addition, female horn-cores and dental remains of small gazelles, as

334 well as remains of other tribes (e.g., Cephalophini), may be confused with them. Geraads et 335 al. (2013a) recognized two species at Kanapoi that they called ?Raphicerus sp. A and 336 ?Raphicerus sp. B; they removed the smaller Madoqua from the Kanapoi faunal list. More 
material has come to light during the last few years; it confirms the absence of Madoqua, but does not improve the distinction between the two or more taxa that are present. All available $\mathrm{m} 3 \mathrm{~s}$ have a relatively large third lobe, unlike in the modern Madoqua and Rhynchotragus in which it is reduced or absent.

We tentatively leave in Raphicerus?, the smaller taxon represented by some dental remains (SOM Table 1) and at least the incomplete horn-core KNM-KP 49373, which is almost straight, but it now seems to us more likely that the larger one is instead a small species of Gazella (see below).

\section{Tribe Cephalophini}

Gen. et sp. indet.

KNM-KP 59788 is an upper molar of small size $($ length $=9.3 \mathrm{~mm}$; width $=8.1 \mathrm{~mm}$ ) that much differs from those of Raphicerini and Antilopini in its very strong paracone rib and weak mesostyle; however, the latter looks less reduced than in modern Cephalophus or than in the very rare fossil representatives of this tribe from Laetoli (Gentry, 1987:Pl. 10.6) or Woranso-Mille (Geraads et al., 2009b:Fig. 2I). Cephalophins are mostly forest-dwellers and are always quite rare in the fossil record. This tooth adds a new taxon to the Kanapoi faunal list and indicates the presence of heavy cover in the surroundings. Size alone is unable to explain the scarcity of this family in the Kanapoi collection compared to other similar-sized bovids, but it may be that other taphonomic factors limited the number of its remains.

Tribe Antilopini Gray, 1821

Genus Gazella Blainville, 1816

Gazella sp.

The horn-cores KNM-KP 29264 and KNM-KP 29270 (Harris et al., 2003:Fig. 26) almost certainly belong to the same taxon, as surmised by Geraads et al. (2013a), who tentatively assigned them to the Reduncini, while observing that they differ in important features from other members of this tribe. In addition to the differences that they listed, we observe that none of the teeth recently unearthed at Kanapoi is definitely attributable to the reduncins, and we consequently now favor an alternative identification and regard them as close to Gazella. Harris et al. (2003) identified KNM-KP 29264 as Gazella sp., but referred KNM-KP 29270 to Damalacra. 
These horn-cores are remarkable in their virtually straight course, with only a very slight forward curvature in their second half, and in the probably correlated characters of small to moderate transverse compression and tendency towards flattening of the anterior surface. Only KNM-KP 29270 can be oriented and is inserted rather obliquely. Other characters of the frontals are not observable, except that they almost certainly lack sinuses. Gazella horn-cores are curved backwards and have a rounded anterior face, and the Kanapoi specimens do not fit within their range of morphological variation. However, their small size, the fact that they do not fit into another tribe, and the occurrence of a number of dental remains of Antilopini whose size matches these horn-cores all support an assignment to this tribe. Small horn cores could be females of the same species (SOM Table 2).

Gazella cf. janenschi Dietrich, 1950

The frontlet KNM-KP 29263 that Harris et al. (2003:Fig. 31) identified as Raphicerus sp. is certainly of a female Gazella, as noted by Geraads et al. (2013a), but the slight backward curvature of the horn-cores is unlike KNM-KP 29264 and KNM-KP 29270, and species identity is unlikely. Its morphology and measurements are similar to those of female Gazella dorcas (width over pedicles $=53.2 \mathrm{~mm} ; 47.1-53.5 \mathrm{~mm}$ in five female specimens of the modern form). KNM-KP 56816 (Fig. 1J) is the base of a probably male horn-core, of moderate size, little compressed (basal index: $25.3 \mathrm{~mm} \times 21.8 \mathrm{~mm}$ ), with the maximum diameter located centrally and a slightly flattened lateral surface. The pedicle is distinctly narrower than the horn-core proper, as in a specimen of Gazella janenschi from Laetoli (Gentry, 2011:Fig. 15.9B), and other characters of this horn-core, especially the poor transverse compression, also fit this species. However, no other specimen allows us to assess the variation and it is safer not to attempt a formal identification.

Several recently found horn-core pieces resemble KNM-KP 29263. In addition, it now seems more likely that most of the dental specimens assigned by Geraads et al. (2013a) to ?Raphicerus sp. B belong instead to Gazella (measurements: SOM Table 1). On the partial mandible KNM-KP 56878, which is definitely too small to belong to Gazella, the third lobe of $\mathrm{m} 3$ has a central valley, showing that the main criterion that Gentry (1980) used to distinguish lower dentitions of Raphicerus from those of Gazella at Langebaanweg does not work at Kanapoi, leaving size as the only available feature. On this basis, and given the occurrence of a species of Gazella of small size, it is more parsimonious to include all specimens larger than Raphicerus into this genus. 
406 Genus indet., aff. Dytikodorcas sp.

Geraads et al. (2013a) revised the identification of the braincase with right horn-core KNM-KP 29277 identified as Aepyceros by Harris et al. (2003:Fig. 28) and tentatively assigned it to the Antilopini, especially because of its complicated frontoparietal suture (Fig. $1 \mathrm{E})$, but it is certainly distinct from the most common antilopins of Africa, Gazella, and Antidorcas. Very few other representatives of this tribe have been identified in this continent.

413 The horn-cores from Omo Shungura Member C identified as Antilope aff. subtorta by Gentry 414 (1985) are smaller and more twisted. The horn-core of KNM-KP 29277 resembles those of 415 'Prostrepsiceros' libycus Lehmann and Thomas, 1987 from Sahabi, although they differ in the 416 lack of a longitudinal groove and the presence of faint transverse ridges. Prostrepsiceros is a 417 late Miocene genus best known from the Eastern Mediterranean, and Bouvrain and Bonis 418 (2007) tentatively reassigned the Sahabi species to their new genus Dytikodorcas, whose type419 species is from the latest Miocene of Greece. Inclusion of the Kanapoi form in the 420 Prostrepsiceros-Dytikodorcas group remains tentative, but if this group is indeed close to the ancestry of Antilope (Gentry, 2008), the occurrence of one of its members at Kanapoi is plausible.

Biogeographic and ecological comparisons $T$. kyaloi is most common in Turkana Basin strata chronologically close to the Kanapoi Formation. The holotype, KNM-WT 18673, derives from the lowermost Kataboi Mb of the Nachukui Fm, dating to about 3.9 Ma (this specimen was originally published incorrectly as deriving from the Lokochot $\mathrm{Mb}$ ). There are several specimens of T. kyaloi from the Apak Mb of the Nachukui Fm dated to $>4.2 \mathrm{Ma}$. The species is also relatively common at the top of the Lonyumun Member of the Koobi Fora Formation, about $4 \mathrm{Ma}$, an interval well sampled at Allia Bay. In higher stratigraphic levels, T. kyaloi is rare. Turkana paleolandscapes became dominated by the Moiti floodplain after 3.9 Ma (Feibel, 2011) and the bovid fauna experienced major changes likely as a result of this remodelling of the hydrology of the basin: Reduncini became more common on the east side, while a mix of bovid tribes were co-dominant on the west side of the basin (Bobe, 2011). has mostly Tragelaphus and Aepyceros, probably both of different species than at Kanapoi. In 437 the later Usno Fm and in the lower part of the Shungura Fm (Gentry, 1985), these taxa are 438 joined by reduncins, making the assemblage still more different from the Kanapoi one. 
Further north, the earliest faunas of Pliocene age are from the Kuseralee $\mathrm{Mb}$ of the

440 Sagantole Fm (Haile-Selassie et al., 2009) in the Middle Awash. They document the late survival of boselaphins in East Africa; the most common bovid is the earliest member of the T. nakuae lineage, and impalas and various reduncins are present, but there is no alcelaphin. The c. 4.4 Ma faunas of Aramis (White et al., 2009) and other contemporaneous sites have not been studied in detail yet, but the overwhelming majority of bovids at Aramis have been identified as T. kyaloi, Aepyceros being much less common and all other Bovidae (including reduncins) rare. It is hard to escape the conclusion that such an assemblage attests to a more wooded environment than at Kanapoi, but the lack of detailed study prevents taxonomic comparisons. The Damalops sp. of White et al. (2009) and Vrba (1997) is the Damalborea of Gentry (2010) and might therefore be identical with one of the Kanapoi alcelaphins, so that taxonomically the Aramis fauna is rather close to that of Kanapoi.

In the c. 3.5-3.7 Ma sites of Woranso Mille (Geraads et al., 2009b), the most common form is an Aepyceros probably identical with the Kanapoi one, but both T. saraitu and the bovin belong to lineages absent at Kanapoi. Similarities with Kanapoi are a form close to Damalborea, as well as the presence of raphicerins, antilopins, and cephalophins, and virtual absence of reduncins.

The Nkondo and Warwire faunas in the Albertine Rift Valley of Uganda (Geraads and Thomas, 1994), probably of early to middle Pliocene age, have bovins, reduncins, and alcelaphins that are hard to identify, an Aepyceros perhaps close to the Mursi one, and two tragelaphins of which the larger one is close to T. saraitu. They are thus clearly East African in character.

By contrast, Pliocene faunas from Kolle in Chad (Geraads et al., 2009a) sharply differ from East African ones in the absence of tragelaphins. Reduncins are common and the bovin Jamous is quite unlike East African forms; the only possible similarity is in the hippotragin Tchadotragus, whose identification at Kanapoi is very tentative.

Turning to the south, the site of Kantis near Nairobi (Mbua et al., 2016), dated to c. 3.5

$466 \mathrm{Ma}$, is unique in being dominated by alcelaphins and impalas that look different from the 467 Kanapoi ones, tragelaphins and reduncins being quite rare. The slightly older fauna of the upper Laetolil Beds, c. 3.6 Ma, includes 15 species (Gentry, 1987, 2011) and shares with

469 Kanapoi a significant number of Raphicerini and Gazella, and the virtual absence of

470 Reduncini. The main taxonomic differences are that there is no evidence of Brabovus and

471 Madoqua at Kanapoi, that the Tragelaphus and Aepyceros are certainly different (small

472 Tragelaphus but large Aepyceros at Laetoli), and that no form similar to Dytikodorcas is 
473

474

475

476

477

478

479

480

481

482

483

484

485

486

487

488

489

490

491

492

493

494

495

496

497

498

499

500

501

502

503

504

505

known from Laetoli. Other differences, in the Hippotragini and Alcelaphini, could largely be explained by the older age of Kanapoi.

No clear biogeographic pattern emerges from these comparisons, as most major taxa range throughout eastern Africa, and the sharp differences between the various sites of the Awash Valley of Ethiopia show that ecological and chronological factors weigh more than geographic ones. In addition, few of the Kanapoi taxa can be identified with enough confidence to draw robust conclusions about their affinities. T. kyaloi is unknown south of Kanapoi, but this might be due to the absence of sites of similar age further south; other resemblances with northern sites are the Aepyceros and the very tentatively identified cf. Tchadotragus and aff. Dytikodorcas. On the other hand, Damalacra harrisi, Simatherium sp., and Gazella cf. janenschi, together with the virtual absence of reduncins, are similarities with the Laetoli assemblage.

Abundance data are presented in Table 1; total numbers by tribe are fairly reliable, but some of the numbers of specimens at lower taxonomic levels are estimates. These data allow the computation of diversity indices (Table 2) using the software PAST (Hammer et al., 2001). The comparison with indices based upon bovid cranial remains of other African sites (Geraads, 1994:Figs. 1 and 2) show that both Shannon H" and Brillouin indices have moderate values at Kanapoi, below those reached around the Plio-Pleistocene boundary. This could be because of less favorable conditions, because the African Bovidae had not yet reached the climax of their diversity, or merely because the great number of Tragelaphus horn cores, perhaps a taphonomic bias (they are more robust than those of the alcelaphins), decreases the value of these indices at Kanapoi.

Ecological interpretations have often been drawn from the relative abundance of bovid tribes and a correspondence analysis allows visualizing their proximity to the main East African sites of this time period (Fig. 5). However, no obvious pattern emerges from this analysis. Probably because all sites are constrained within a relatively short period (from c. 5.2 Ma for the Kuseralee Member to c. 3 Ma for Shungura Member B), time is not a major factor. Axis 1 may reflect a South-North gradient, although this could merely be due to the open conditions at Laetoli and Kantis (which are also at a greater altitude). Kanapoi clearly differs from these southern sites, but also differs from most Turkana localities in the low abundance of reduncins and dominance of Tragelaphus and Aepyceros, attesting to a large proportion of bush or arboreal cover, and resembling instead in this regard the Ethiopian sites of Aramis and Woranso-Mille. Still, despite these variations in bovid proportions, all these 
506 sites cluster together, testifying to similar environmental conditions, obviously suitable for the

507 closely related hominin species that thrived there.

508

\section{Conclusions}

510 The Pliocene site of Kanapoi documents at least 16 species of Ruminantia in two

511 families (Giraffidae and Bovidae) with some 300 collected specimens. The Giraffidae include

512 G. jumae, G. pygmaea, and Sivatherium cf. hendeyi. Sivatherium at Kanapoi is exceedingly

513 rare, known from only a few specimens. Among bovids, Tragelaphini is the dominant tribe,

514 followed by Alcelaphini and Aepycerotini. These three tribes make up almost $75 \%$ of the

515 identified Kanapoi bovids. The taxonomic composition of the dominant bovid groups and

516 their stable isotopic signatures indicate a mosaic of wooded and grassy habitats at Kanapoi in

517 the Pliocene. The absence (or rarity) of Reduncini suggests that regularly flooded grasslands

518 were not a major component of the local vegetation. The description of Kanapoi bovids

519 provided here serves as a basis for further paleoecological research at the site of the earliest

520 species of Australopithecus.

\section{Acknowledgments}

We are grateful to C. Ward, F.K. Manthi, and M. Plavcan for having invited us to

524 participate in this special issue about Kanapoi and to all people who allowed us to access

525 modern and fossil collections in their care during the last decades: C. Argot and J. Lesur

526 (MNHN), P. Brewer and A. Currant (NHMUK), G. Senichaw (NME), M. Muungu (KNM),

527 and A. Prieur (FSL). Thanks also to two anonymous reviewers for their helpful comments.

528 Recent field work at Kanapoi was supported by NSF grants BCS-1231749 (to C. Ward and

529 F.K. Manthi), BCS-1231675 (to M. Plavcan and P. Ungar), the Wenner Gren Foundation, the

530 University of Missouri Research Board, and PAST of South-Africa. 


\section{References}

534 Bibi, F., 2011. Tragelaphus nakuae: evolutionary change, biochronology, and turnover in the African Plio-Pleistocene. Zool. J. Linn. Soc. 162, 699-711.

Bobe, R., 2011. Fossil mammals and paleoenvironments in the Omo-Turkana Basin. Evol. Anthropol. 20, 254-263.

Bouvrain, G., Bonis, L. de, 2007. Ruminants (Mammalia, Artiodactyla: Tragulidae, Cervidae, Bovidae) des gisements du Miocène supérieur (Turolien) de Dytiko (Grèce). Annl. Paléontol. 93, 121-147.

Cerling, T.E., Andanje, S.A., Blumenthal, S.A., Brown, F.H., Chritz, K.L., Harris, J.M., Hart, J.A., Kirera, F.M., Kaleme, P., Leakey, L.N., Leakey, M.G., Levin, N.E., Manthi, F.K., Passey, B.H., Uno, K.T., 2015. Dietary changes of large herbivores in the Turkana Basin, Kenya from 4 to 1 Ma. Proc. Natl. Acad. Sci. 112, 11467-11472.

Cooke, H.B.S., Coryndon, S.C., 1970. Pleistocene Mammals from the Kaiso Formation and other related deposits in Uganda. Fossil Vertebr. Afr. 2, 107-224.

Drapeau, M., Bobe, R., Wynn, J., Campisano, C., Dumouchel, L., Geraads, D., 2014. The Omo Mursi Formation: a window into the East African Pliocene. J. Hum. Evol. 75, 64-79.

Erdbrink, D.P.B., 1988. Protoryx from three localities East of Maragheh, N.W. Iran. Proc. K. Ned. Akad. Wetensch. B 91, 101-159.

Fennessy, J., Bidon, T., Reuss, F., Kumar, V., Elkan, P., Nilsson, M.A., Vamberger, M., Fritz, U., Janke, A., 2016. Multi-locus analyses reveal four giraffe species instead of one. Curr. Biol. 26, 1-7.

Gentry, A.W., 1980. Fossil Bovidae (Mammalia) from Langebaanweg, South Africa. Annl. Transv. Mus. 79, 213-337.

Gentry, A.W., 1996. A fossil Budorcas from Africa. In: Stewart, K.M., Seymour, K.L. (Eds.), career of C.S. (Rufus) Churcher. University of Toronto Press, Toronto, pp. 571-587. 
Gentry, A. W., 2006. A new bovine (Bovidae, Artiodactyla) from the Hadar Formation, Ethiopia. Trans. R. Soc. South Afr. 61, 41-50.

Gentry, A.W., 2008. New records of Bovidae from the Sahabi Formation. Garyounis Sci. Bull. (Special Issue) 5, 205-217.

Gentry, A.W., 2010. 38. Bovidae. In: Werdelin, L., Sanders, W.J. (Eds.), Cenozoic Mammals of Africa. University of California Press, Berkeley, pp. 741-796.

Gentry, A.W., 2011. 15. Bovidae. In: Harrison, T. (Ed.), Paleontology and Geology of Laetoli: Human Evolution in Context, vol. 1. Springer, New York, pp. 363-465.

Geraads, D., 1994. Evolution of Bovid diversity in the Plio-Pleistocene of Africa. Hist. Biol. 7, 221-237.

Geraads, D., 1998. Le gisement de Vertébrés pliocènes de Çalta, Ankara, Turquie: Cervidae et Giraffidae. Geodiversitas 20, 455-465.

Geraads, D., Thomas, H., 1994. Bovidés du Plio-Pléistocène d'Ouganda. In: Pickford, M., Senut, B. (Eds.), Geology and Palaeontology of the Albertine Rift valley, UgandaZaire. CIFEG occas. Publ. 29, 383-407.

Geraads, D., Blondel, C., Likius, A., Mackaye, H.T., Vignaud, P., Brunet, M., 2008. New Hippotragini (Bovidae) from the late Miocene of Toros-Menalla, Chad. J. Vertebr. Paleontol. 28, 231-242.

Geraads, D., Blondel, C., Mackaye, H.T., Likius, A., Vignaud, P., Brunet, M., 2009a. Bovidae (Mammalia) from the lower Pliocene of Chad. J. Vertebr. Paleontol. 29, 923-933.

Geraads, D., Melillo, S., Haile-Selassie, Y., 2009b. Middle Pliocene Bovidae from Hominidbearing sites in the Woranso-Mille area, Afar region, Ethiopia. Palaeontol. Afr. 44, $59-70$.

Geraads, D., Bobe, R., Reed, K., 2012. Pliocene Bovidae (Mammalia) from the Hadar Formation of Hadar and Ledi-Geraru, Lower Awash, Ethiopia. J. Vertebr. Paleontol. 32, 180-197.

Geraads, D., Bobe, R., Manthi, F.K., 2013a. New ruminants (Mammalia) from the Pliocene of Kanapoi, Kenya, and a revision of previous collections, with a note on the Suidae. J. Afr. Earth Sci. 85, 53-61.

Geraads, D., Bobe, R., Reed, K., 2013b. Pliocene Giraffidae (Mammalia) from the Hadar Formation of Hadar and Ledi-Geraru, Lower Awash, Ethiopia. J. Vertebr. Paleontol. $33,470-481$.

Grubb, P., 2001. Review of family-group names of living bovids. J. Mamm. 82, 374-388. 
Haile-Selassie, Y., Vrba, E.S., Bibi, F., 2009. 9. Bovidae. In: Haile-Selassie, Y., WoldeGabriel, G. (Eds.), Ardipithecus kadabba - Late Miocene Evidence from the Middle Awash, Ethiopia. University of California Press, Berkeley, pp. 277-330.

Hammer, Ø., Harper, D.A.T., Ryan, P.D. 2001. PAST: Paleontological statistics software package for education and data analysis. Palaeont. Electr. 4(1), 9.

Harris, J.M., 1976a. Pleistocene Giraffidae (Mammalia, Artiodactyla) from East Rudolf, Kenya. Fossil Vertebr. Afr. 4, 283-332.

Harris, J.M., 1976b. Pliocene Giraffoidea (Mammalia, Artiodactyla) from the Cape Province. Annl. S. Afr. Mus. 69, 325-353.

Harris, J.M., 1991. Family Bovidae. In: Harris, J.M. (Ed.), Koobi Fora Research Project. Volume 3: The fossil ungulates: Geology, Fossil artiodactyls and palaeoenvironments. Clarendon Press, Oxford, pp. 139-320.

Harris, J.M., Leakey, M.G., Cerling, T.E., Winkler, A.J., 2003. Early Pliocene tetrapod remains from Kanapoi, Lake Turkana Basin, Kenya. In: Harris, J.M., Leakey, M.G. (Eds.), Geology and Vertebrate Paleontology of the Early Pliocene site of Kanapoi, Northern Kenya (Contributions in Science 498). Natural History Museum of Los Angeles County, Los Angeles, pp. 39-113.

Lehmann, U., Thomas, H., 1987. Fossil Bovidae (Mammalia) from the Mio-Pliocene of Sahabi, Libya. In: Boaz, N.T., El-Arnauti, A., Gaziry, A.W., Heinzelin, J. de, Dechant Boaz, D. (Eds.), Neogene Paleontology and Geology of Sahabi. Alan R. Liss, New York, pp. 323-335.

Mbua, E., Kusaka, S., Kunimatsu, Y., Geraads, D., Sawada, Y., Brown, F., Sakai, T., Boisserie, J.R., Saneyoshi, M., Omuombo, C., Muteti, S., Hirata, T., Hayashida, A., Iwano, H., Danhara, T., Bobe, R., Jicha, B., Nakatsukasa, M., 2016. Kantis: A new Australopithecus site on shoulders of the Rift Valley, near Nairobi, Kenya. J. Hum. Evol. 94, 28-44.

Reed, K., Bibi, F., 2010. Fossil Tragelaphini (Artiodactyla: Bovidae) from the Late Pliocene Hadar Formation, Afar Regional State, Ethiopia. J. Mammal. Evol. 18, 57-69.

Rowan, J., Locke, E.M., Robinson, J.R., Campisano, C.J., Wynn, J.G., Reed, K.E., 2016. Fossil Giraffidae (Mammalia, Artiodactyla) from Lee Adoyta, Ledi-Geraru, and Late Pliocene Dietary Evolution in Giraffids from the Lower Awash Valley, Ethiopia. J. Mammal Evol. DOI 10.1007/s10914-016-9343-z

Vrba, E.S., 1997. New fossils of Alcelaphini and Caprinae (Bovidae: Mammalia) from Awash, Ethiopia, and phylogenetic analysis of Alcelaphini. Palaeontol. Afr. 34, 127- 
198.

634 White, T.D., Ambrose, S.H., Suwa, G., Su, D.F., DeGusta, D., Bernor, R.L., Boisserie, J.-R., Brunet, M., Delson, E., Frost, S., Garcia, N., Giaourtsakis, I.X., Haile-Selassie, Y., Howell, F.C., Lehmann, T., Likius, A., Pehlevan, C., Saegusa, H., Semprebon, G., Teaford, M., Vrba, E., 2009. Macrovertebrate paleontology and the Pliocene habitat of Ardipithecus ramidus. Science 326, 87-93.

639 Yang, C., Xiang, C., Qi, W., Xia, S., Tu, F., Zhang, X., Moermond, T., Yue, B. 2013.

640 Phylogenetic analyses and improved resolution of the family Bovidae based on complete mitochondrial genomes. Biochem. Syst. Ecol. 48, 136-143.

642 


\section{Figure legends}

644 Figure 1. A-D) Tragelaphus kyaloi. A) KNM-KP 58836, braincase with left horn-core, left 645 lateral view. B) KNM-KP 30156, frontlet in front view. C) KNM-KP 68, posterior part of 646 braincase, left lateral view; note the backwardly directed paroccipital process. D) KNM-KP 64756829 , distal view of right horn-core fragment, showing the outline of the cross-section. E) 648 aff. Dytikodorcas sp., KNM-KP 29277, braincase in dorsal view, showing the complicated 649 fronto-parietal suture. F-G) cf. Tchadotragus sp. F) Right upper molar KNM-KP 56843. G) 650 Left upper molar KNM-KP 59763. H) Giraffa jumae, left ossicone KNM-KP 58739 in H1, 651 lateral, and H2, posterior views. I) Giraffa pygmaea, incomplete ossicone KNM-KP 59918 in 652 I1, ?medial, and I2, ?anterior views. J) Gazella cf. janenschi, left horn-core KNM-KP 56816 653 in J1, lateral, J2, anterior, and J3, medial views. Scale bar = $5 \mathrm{~cm}$ for F-G; $10 \mathrm{~cm}$ for C-E, I-J; $65420 \mathrm{~cm}$ for A-B, H.

655

656 Figure 2. Plot of distal width vs. medial height in fossil and modern Giraffa astragali 657 (although some of the largest ones may belong to Sivatherium) and in the Hadar Formation 658 bovin Ugandax.

659

660 Figure 3. Sketch-drawing comparing the cranial profile of a 'normal' Tragelaphus

661 (Tragelaphus spekei) with that of Tragelaphus kyaloi (based upon KNM-KP 58836). 662

663 Figure 4. Plot of antero-posterior vs. transverse diameters of Tragelaphus horn-cores. Note 664 the wide range of measurements at Kanapoi.

665

666 Figure 5. Correspondence analysis of the main African bovid tribes (excluding the rare 667 Boselaphini, Cephalophini, and Brabovus) and major East African Lower and Middle 668 Pliocene sites (data in SOM Table 3). 